\title{
PSYCHOLOGICAL BASIS OF THE IMAGE OF A DEAD LOVER IN MYTHOLOGY OF TRANSCARPATIA AND P. KULISH'S STORY ABOUT, WHY THE PESHEVTSOV POND WAS DRIED UP IN THE TOWN OF VORONEZH
}

\section{Tykhovska Oksana}

Candidate of Sciences in Philology, Associate Professor

ORCID ID 0000-0003-4663-5960

SHEE «Uzhhorod National University»

Narodna Square, 3, Uzhhorod, 88000, Ukraine

oksana.tykhovska@uzhnu.edu.ua

In Ukrainian mythology as in world mythology, there is an idea of the possibility of a love relationship between a human and a demonic creature - a dead lover or a devil. Thus, F. Potushnyak's article Dead Love in Folk Beliefs (1944) is devoted to this theme.

Folk beliefs about demonic lovers precondition the relationship between them and a human, and methods of their overcoming are examined in this article. In the short story About, why the Peshevtsov pond was dried up in the town of Voronezh (1839) written by $P$. Kulish, we can find a very interesting interpretation of folk beliefs when a dead husband visits his wife. The writer modeled the tragic story of the woman, whose husband disappeared, with the help of folk mythological stories. And because of her deep regret, she became a victim of a demon who appeared in the image of her beloved husband. In the article, the psychological basis of the appearance of visions, in which the main figure is a dead object of love, is analyzed. Through the prism of Jung's theory, the image of a dead lover is considered as a personification of one of the archetypes of the collective unconscious (Animus, its negative aspect). Destructive display of this image has the same psychological basis both in mythological legends and in P. Kulish's short story About, why the Peshevtsov pond was dried up in the town of Voronezh. The woman's consciousness refuses to take the reality as it is and creates an alternative variant for herself - the dead lover comes to her at night (when unconscious dominates - our wishes, fears, etc. are implemented in night dreams). The line between conscious and unconscious life is erased and the woman becomes a hostage of her own fantasy, which removes pain of loss and gives hope to renew the lost emotional and spiritual balance for a moment. Folk stories in the spirit of Christian morality contain "recipes" of fighting a dead lover. However, mostly these rituals cannot help the woman, who is obsessed with love to her dead lover as it happened in P. Kulish's story.

Key words: folk beliefs, perelesnyk, psychoanalysis, romanticism, P. Kulish, Ukrainian mythology, F. Potushnyak.

\section{ПСИХОЛОГІЧНЕ ПІДГРУНТЯ ОБРАЗУ МЕРТВОГО КОХАНОГО В МІФОЛОГІЇ ЗАКАРПАТТЯ ТА ОПОВІДАННІ П. КУЛІША «О ТОМ, ОТ ЧЕГО В МЕСТЕЧКЕ ВОРОНЕЖЕ ВЫСОХ ПЕШЕВЦОВ СТАВ»}

Тиховська Оксана

Кандидат філологічних наук, доцент ORCID ID $\underline{0000-0003-4663-5960}$

ДВНЗ «Ужгородський національний університет» пл. Народна, 3, Ужгород, 88000, Україна oksana.tykhovska@uzhnu.edu.ua

(C) Tykhovska O., 2020 
В украӥнській, як і в світовій міфологї, побутують уявлення про можливість любовних стосунків між людиною та демонічною істотою - покійним коханим або ж чортом. Зокрема, иій темі присвячена стаття закарпатського етнографа та фольклориста Ф.Потушняка ««Мертва любов» въ нар. вгоруваню» (1944), де розглянуто народні вірування про демонічних коханців, передумови встановлення зв'язку між ними ц̌ людиною та способи їх подолання. Цікаву художню інтерпретацію народних вірувань про побачення жінки з покійним чоловіком знаходимо в оповіданні П.Куліша «О том, от чего в местечке Воронеже высох Пешевцов став» (1839). Письменник, відштовхуючись від народних міфологічних оповідей, змоделював трагічну історію жінки, котра через гіркий сум за своӥм зниклим чоловіком стала жертвою демона, щзо постав перед нею в образі коханого. У статті проаналізовано психологічні передумови появи видінь, в яких фігурує померлий об'єкт кохання. Крізь призму теорії К.-Г. Юнга образ мертвого коханого розглянуто як персоніфікачію одного з архетипів колективного несвідомого (Анімуса, його негативного аспекту). Руйнівний вияв изього образу в міфологічних легендах та в оповіданні П.Куліша «О том, от чего в местечке Воронеже высох Пешевцов став» має однакове психологічне підгрунтя. Свідомість жінки відмовляється сприймати реальність такою, якою вона є насправді, й створює для себе альтернативний варіант - мертвий коханий постає в образі живого вночі (коли власне й домінує несвідоме - у нічних сновидіннях реалізовуються наші бажання, страхи тощо). Межа між свідомим i несвідомим життям, між неспанням $i$ сновидінням стирається, жінка стає заручницею власної фантазії, яка усуває біль утрати й на якусь мить дарує надію на відновлення втраченої емоиійно-духовноі рівноваги. Народні оповіді в дусі християнської моралі містять «рецепти» боротьби з мертвим коханим, однак у більшості випадків, як $і$ в оповіданні П.Куліша, магічні ритуали не здатні врятувати жінку, одержиму коханням до померлого.

Ключові слова: народні вірування, перелесник, психоаналіз, романтизм, П.Куліш, українська міфологія, Ф.Потушняк.

The folk beliefs of Ukrainians of Transcarpathia about a love relationship between a living person and a dead object of love are considered in F. Potushnyak's folklore and ethnographic work "The Dead Love in Folk Beliefs" which was published in the middle of the XXth century. This work has not been the object of the research till now. Many folk beliefs fixed by F. Potushnyak have something in common with motives of P. Kulish's story "About, why the Peshevtsov pond was dried up in the town of Voronezh". The image of a dead lover is very similar to the image of a perelesnyk, a demon, a devil, a vampire or a two-soul man in Slavonic mythology. Folk beliefs of such demonological images can be found in the works of N. Varkhol, L. Vynogradova, V. Gnatyuk, O. Poritska, P. Chubynskiy, V. Shukhevych.

Relevance of this article is predetermined by the typological analysis of folk beliefs of Transcarpathia about a love relationship between a human and a dead man/two-soul man and reconsidering similar beliefs by P. Kulish in his story "About, why the Peshevtsov pond was dried up in the town of Voronezh". The typological parallels which were made in the article help to understand the specifics of the mythological motive mentioned above in the folk beliefs of Eastern and Western Ukraine and have features for their reconsidering in literary work.

P. Kulish's story "About, why the Peshevtsov pond was dried up in the town of Voronezh" is less researched, but a very interesting analysis of its folklore basis was made by V. Ivashkiv. [3, p. 36-41]. The researcher focused on the specifics of mythologism of this story. He specified precisely that "Kulish usually introduces a mythological element for literary work only when the character breaks some (as usual Christian, god-fearing) norm (code) of behavior: communication of a young wife with her beloved husband, who left home with chumaks, with the help of dark power" [3, c. 34]. According to V. Ivashkiv the idea of the story "About, why the Peshevtsov pond was dried up in the town of Voronezh" 
consists in inevitableness of human atonement for this relationship (which was not realized by the heroine here) with mysterious, supernatural, "black" power and it is evident because of the motive of premonition [...], which becomes the motive of distress for the lover" [3, p. 40].

Aim of the article is to consider special features of the image of a dead lover in folk beliefs of Transcarpathia and in P. Kulish's story "About, why the Peshevtsov pond was dried up in the town of Voronezh" in the light of psychoanalysis emphasizing on the semantics of archetypical images.

The subject area of the research is the folklore and ethnographic work "The Dead Love in Folk Beliefs" written by F. Potushnyak and the story "About, why the Peshevtsov pond was dried up in the town of Voronezh" written by P. Kulish.

The specific topic of the research is the image of a dead lover in the F. Potushnyak's work and P. Kulish's story.

Methods of the research: psychoanalytical, structural-semantic, structural-typological, comparative-historical, genetic.

Obviously, the myths of a love relationship between gods and women caused the appearance of beliefs about communication between a woman and her demonic lover. In particular, A. Calmet studied such folklore stories and stressed that "belief of physical contacts between gods and people can be found in ancient pagan religion. Priests claimed the plan of some god to contact with some woman [...] A priest brought the invited person to the temple and left her there for all night. At midnight a god came into the temple and spent some time with the woman. [...] Many ancient people, especially Persian and Egyptian, had such kind of customs. [...] According to Greek mythology, Zeus visited women very often with that purpose" [4, p. 97]. Later, according to F. Potushnyak, "on the basis of that belief the set of rituals appeared. It deals with saint prostitution (direct or indirect which means to spend the night in the church for rehabilitation)" [8, p. 33].

Some gods transformed into spirits and demons in folk imagination with decay of pagan religion and ideas about perelesnyks, perelesnyts, incubus and succubus appeared. P. Chubynskyi described the ideas of Ukrainians about perelesnuk: «Perelesnyk is an evil spirit which appeared in front of somebody in the image of a dead lover. A great amount of young people who miss their lovers can see perelesnyks. They appear in front of such inexperienced people, talk to them, kiss them and satisfy their passion. But it is not good for this person - she or he loses weight and then dies". [9, p. 193]. N. Varkhol mentioned perelesnyk in her works in such a way: "According to folk beliefs of Ukrainians of Slovak Republic, perelesnyk is a tempter of young women. He flies in the air and appears in the image of a lover at night. This male demonic creature mainly hurts a person who is unlucky in love" [2, p. 121]. In the world mythology there were similar creatures - incubi - male demons who wanted intimate relations with women. Incubi caused terrible dreams and hallucinations; they made illusion of intimate relationship on the unconscious level of a victim. A female analogue of this demon is called succubus (a female-demon who seduced men in night dreams). F. Potushnyak mentioned these personages as a form of "otherness of god" in the mythology of Egypt, Judea, Greece. According to his observation, in Babylonian magic "notion of demon called Ardat Lily was described the most vividly. This demon divided into male and female forms: Lila (incubus) and Lilit (succubus) and they had the features of an air demon" [8, p. 32], and then, in the medieval times, the features of a devil. These demons seem to be "air demons" maybe because they had connection with a dream when a human soul can fly as a bird. "That air character (as phenomenon of a dream) found its reflection in the belief of Romans: the spirit of the forest appeared in a person's dream and had sexual intercourse with her as elfs, kobolds, veelas or our povitrulyas and others" [8, p. 32], - wrote F. Potushnyak.

Lately stories about a love relationship between a human and a devil or even a dead man appeared in Ukrainian folklore. The folklorist, M. Dmytrenko, recorded some of such stories: "Coming dead man" [7, p. 110], "Why dead men come and how to ward they off" 
[7, p.111], "The deceased comes to a woman" [7, p. 109-110], "Don't cry for a dead for a long time" [7, p.107], "A dead husband comes to his wife" [7, p. 114-115] .

There is an interesting interpretation of folk beliefs when a woman meets a demon in the image of her absent (maybe dead) husband in P. Kulish's story "About, why the Peshevtsov pond was dried up in the town of Voronezh". On the basis of folk mythological stories, the writer simulated a tragic story of a woman who missed her lost husband very much and, because of this great sadness, she became a victim of a demon which was in the image of her lover. Natalka, the main heroine of the story, was described by P. Kulish as an intuitive, emotionally impressible type, she has close connection with unconsciousness, but she is not able to resist destructive influence because of certain infantile attitude. Particularly, before her husband Hrytsko left home and went to Crimea, Natalka had felt that something terrible would happen and she would not see her husband alive again. In the spirit of a romantic style P. Kulish described thoughts and psychological state of the heroine: "She hugged him crazily and sobbed violently and she could not say farewell words to him [...] When her husband left home Nataka cried bitterly as if he died". [5, c. 209]. Thus, P. Kulish masterfully made a story situation which can be interpreted in two ways: 1) Natalka's consciousness models pictures of possible death of her lover and in such a way she helps to materialize them (such a psychological attitude is typical for mythological outlook which implies the possibility of materialization of thoughts, desires or fears); 2) Natalka has a close spiritual and emotional connection with Hrytsko and she intuitively predicts what will happen in the future and this unconscious knowledge generates pain and sufferings.

P. Kulish made artistic reception of folk beliefs describing time and preconditions of activity of demonic power in the story "About, why the Peshevtsov pond was dried up in the town of Voronezh". "Here the full moon shines brightly [...] but it is silent, it is empty under the sky [...] in an hour after the midnight, - when all alive fall asleep and the life, which is unknown to the people, begins. In that time unbaptized children roll on the cold wet grass and climb the cherry-tree in the light of the moon in the dark gardens. At the cemetery recently buried people, who grieve for this world, come out of their airless graves and swing on the crosses [...] And around the pond some shades slither the wet shores, but they are so light and weak that they cannot go through the air with their sound; they only move back and forth as foggy haze" [5, p. 209-210]. At the same time this episode will prepare the reader for further development of the events where all beliefs come to life and become a reality for Natalka. After midnight when there is a full moon in the sky, all people sleep and the time of demonic activity begins and Natalka does not sleep. And according to logic of the story, this violates normal life and the heroine joins the world of darkness and becomes open for the communication with the representatives of the other world. "As pale as a shadow she sits on the doorstep of her cellar opposite to the moon and thinks about Hryts...[...] Oh dear, fly to me as a falcon or an eagle! Oh, come to me my dear Hryts! Come to me at least for an hour...break up sadness in my heart..." [5, p. 210]. Natalka makes magical actions intuitively: she says her request on the doorstep and, according to the folk beliefs, this place is a border between the worlds (here demonic creatures can appear); she looks at the moon and asks it to make her wish come true. The answer to such an emotionally desperate request is materialization of the heroine's wish - suddenly Hryts appears. Natalka tries to get to know how he can appear near her, because he is so far away, somewhere in Crimea. The heroine wants to explain herself the possibility of such a relocation of Hryts through space and time, "she began to examine him from head to foot. But it was really him, he was definitely her Hryts! She was very happy and at the same time she felt some fear. But Hryts hugged her - and love spoke more loudly than fear" [5, p. 212].

Her husband urged her not to ask him how he appeared near her and kept their meetings in secret: "I will tell you everything but not now. Keep silent, for God's sake; do not tell anybody about me, otherwise it will be bad for us!" [5, p. 211]. The woman's consciousness refuses to perceive reality as it is and creates an alternative variant - an 
imaginary demonic creature in the image of her husband appears at night suddenly (when unconsciousness dominates - our wishes and fears are realized in our dreams). A border between conscious and unconscious, between dreams and sleeplessness erases, Natalka becomes a hostage of her own fantasy, which takes away the pain of solitude and, for some time, gives her hope for retrieval of a lost emotional-spiritual balance.

An alternative reality, created by a psyche of a person exhausted by the grief, seems to be very plausible. In his article F. Potushnyak analyzed similar folk beliefs of Ukrainians of Transcarpathia: A dead young woman (young man) visits her lover, kisses him, hugs him and then, they have sexual intercourse" [8, p. 31]. The scholar separates person's "night" and "day" perception of dates with a dead lover. At night impossible can seem as possible, desirable things are realized in dreams or delirium (hallucination): "At night an alive perceives it with fear and is happy as if this is in real life, but she is afraid in the morning" [8, p. 31]. However, in P. Kulish's story Natalka was not afraid at once, she felt fear only after eight meetings with unreal Hrytsko.

According to S. Birkhauser-Oeri, "In psychological terms, fora woman the meeting with the devil could mean anexperience of the negative animus. We are talking about a totally destructive psychological mechanism which can takecontrol of a womanwhenshe approaches the unconscious." [1, p. 122]. Archetype Animus is a personification of male side in the woman's psyche, it periodically and in different ways influences women's behavior, it is "a type of spirituality which is often in need of development. If this does not occur she will fall a victim to a negative animus." [1, p. 53].

As any archetype animus is ambivalent and, that is why in the woman's dreams, myths, fairy tales, mythological stories, its bright and dark aspects are objectified. Negative Animus often appears as a demon, a teratomorphus creature, an evil-minded dead husband or, a ghost. The motive of meetings of Natalka and pseudo-Hrytsko and her refusal to look for a rational explanation of possibility of these meetings is a metaphorical display of a psychological process of the woman's obsession with negative Animus. Natalka modeled the image of an imaginary lover in her dreams and got rid of anguish, despair and fear of loneliness for some time. Reluctance of death acceptance or absence of a lover as a true fact conduced the woman's unconscious to simulate the life scenario where somebody who was dead or was far away from home because of certain circumstances became alive or achievable.

However, the illusiveness of these meetings became evident for Natalka after her conversation with a villager. "On the eighth day, the neighbor, who was with Hrytsko in Crimea, came back home and brought Natalka a present from her husband." [5, p. 212]. The neighbor informed Natalka that her husband came back home very soon and, that fact caused a conflict of two realities, which contradict each other in the heroine's consciousness. Society, rational perception of the other people destroys myth, which is modeled by the woman's unconscious. "Who came to me at night? - thinks Natalka. There was something bad" [5, p. 212]. And awareness of how dangerous and sinful these meetings are takes place in the daytime, after getting objective information from a real person. This made her tell her mother about the night guest.

This mystic situation, which happened to the heroine of the story, was solved with the help of a witchdoctor who explained these night meetings of Natalka and Hrytsko as a result of summoning a soul of her lover (either alive or dead) and gave her recommendations of how to get rid of these meetings. "Natalka missed Hryts too much and she made his soul to come to her [...] Such things happened. A person's soul is very sensitive, it knows what was happening hundreds of miles away, and when a person is happy, it gets to know that something goes bad and, a person becomes sad. And if two souls are sad because they are far away from one another, then the soul who loves stronger summons another one. Oh, then the trouble cannot be avoided: either soul of an alive person and a dead one does not like when somebody summons it" [5, p. 212-213]. Similar description of folk beliefs can be found in F. Potushnyak's article: " Not only a two-soul man but even a usual dead man or woman can come to his/her lover at night, and sexual 
intercourse can happen both in dreams and in reality when there is a reason for this. This happens when they love each other very much during their lives - that is when someone misses the lover very much. Such a kind of love calls the soul back and makes it active (non-magically)..." [8, p. 31]. According to the folk world outlook, the development of such a scenario is sinful and destroys a person's soul, who lived in the past. This person is not able to accept the true reality as it is and simulates an imaginary world comfortable for him/her, avoiding pain and loneliness.

The witchdoctor in the story "About, why the Peshevtsov pond was dried up in the town of Voronezh" explains the nature of a soul as a creature who can feel either its pain or someone else's pain and irrationally gets information. All this reflects the hypothesis of psychoanalysts of the possibility of the contact between the consciousness and unconscious (more exactly between archetypes of the collective unconscious) in certain crucial moments of life, state of affect, aggression, or nervous excitement. It was interesting that Hrytsko's soul, which was coming to Natalka at night, was interpreted by the witchdoctor according to folk beliefs about a two-soul man. F. Potushnyak described the character of those people: "Except for that soul, which leaves the body because of death, there are souls, who are in bodies, but they can leave them and be outside them separately. This can be done only by some people, the so-called "two-soul men". The two-soul man is a person who has one or two souls except for the usual one". [2, p.37]. Thus, Hrytsko's soul who is able to travel when the body sleeps can be interpreted as demonic, it co-exists with a light soul that does not know about the existence of another. In P. Kulish's story "About, why the Peshevtsov pond was dried up in the town of Voronezh" a witchdoctor tells about the results of such traveling of a soul according to the folk beliefs. She says to Natalka's mother: "We will ward off Hrytsko's soul; if it comes back to the previous place and stays there, then thank God for that; but if it does not like Hrytsko's body it will fly all over the world until it calls Natalka's soul and pushes Natalka to death" [5, p. 213]. Thus, the lovers must be together - either alive or dead.

It was found out that Hrytsko's soul was a metaphoric projection of negative Animus of Natalka (her inner masculinity). Generally, the objectification of Animus as a devil is not accidental for Christian women. According to S. Birkhauser-Oeri, "Thedevilis a figure of the Christian imagination. He is the dark complement of God. And so it is not accidentally that Christians, as soon as they turn toward the unconscious, face the problem of suprapersonal evil. It is the fate of anyone rooted in a Christian culture to be confronted with this difficult question as they move away from the surface toward their own depths and at the same time their natural drives [1, p. 122]. Symbols of the fight against Hrytsko show the archetypical nature of his image. When the man came to Natalka for the eighth time, the woman did not respond to him, combing her hair silently and "sat at the doorstep facing a garner" as the witchdoctor suggested to her. [5, p. 213]. Hrytsko got angry because of such Natalka's behavior, "he hit her head and disappeared" [5, p. 214]. From the point of view of psychoanalysis, «hair grows from the head and it could be seen as unconscious thoughts and ideas [...] hair is thus a particularly good image for autonomous parts of the psyche we are unaware of" [1, p. 143]. Evidently, the fact that the heroine combs her hair sitting at the doorstep symbolizes her desire to order her thoughts and realizes their destructive aspect and also the nature of her inner masculinity. The doorstep as a border between the worlds must help to identify and objectify the demonic character of Natalaka's unconscious because spirits and demons could appear at the border at midnight. As it was mentioned above, Natalka sat facing the garner, and this action metaphorically expressed the woman's undesirability to see somebody, who could come through the door, and her desire to avoid the meeting with a night guest.

The result of Natalka's rituals was Hrytko's disappearance and her death on the third day. "She sits on the doorstep at midday on the third day. Suddenly, a black kite flew and caught a chicken. Natalka ran out of the yard. The kite, as if purposely flew away for a little and sat down on the road, and Natalka still was chasing it. When they came up to the pond, it sat on the log protruding from the water. Natalka went into the water to the waist, and 
suddenly she dived into the water, and only black braids floated on the surface." [5, p. 214]. According to the prediction of a witchdoctor, Hrytsko's dark soul does not want to return to his body, and it means that he was dead. His dark nature of a two-soul man was doomed to wander at the border between the worlds. He wanted to be with Natalka and, that is why he, in the image of a black kite, provoked her to die - the woman drowned in the pond, her body disappeared, funeral rituals were not performed, and this was a precondition to her wandering between the worlds together with Hrytsko. According to psychoanalysis, Natalka's death is a result of her obsession with negative Animus, which subordinates a woman's ego and provokes her to suicide. She thought that death was the only way to avoid psychological dissociation and to join her dead husband.

In his article, F. Potushnyak pointed out that in folk imagination, a dead man continued to live, but in the other hypostasis, however, at the same time, he had human needs and was able to communicate with those who were close to him. The appearance of Hrytsko's soul in the image of a kite is shown in P. Kulish's story, according to those folk beliefs. "In that world a dead needed everything that he or she had, when he or she was alive, especially that thing which he or she liked the best; if the needs were not satisfied during the life he or she wanted to achieve them after death." [8, p. 32-33], - wrote F. Potushnyak. Hrytsko went to Crimea unwillingly, because he got married only a month ago. Happy family life, wife's love were those things which Hryts could not enjoy fully, so he took Natalka to the beyond world in case to compensate the lost time.

The human obsession with love to the dead and stories about meeting a dead lover "is considered to be a very awful and difficult phenomenon, which cut to the quick the whole group and filled it with fear, moreover, they do not hesitate that its origin was from the other world. However, it happened either because of the punishment of sins or because of a dead man's desire." [8, p. 31]. F. Potushnyak mentioned different magic rituals and means which can help to get rid of a dead lover. "The house, where an obsessed person lives, has to be consecrated. Holy water, poppy seeds, and a knife are put into bed, "protur" (special stick) has to be hammered into the doorstep for the night, and during the day axe has to lie on the doorstep with the blade looking upwards." [8, p. 31]. A person, who wants to get rid of a demon coming to her, "has to go to the cemetery and before sunset, this person has to throw his or her "ordure" tied up with the rip on the tomb of a dead person who chased him or her. The rip must belong to a dead person (any dead person). When it does not help, and attacks of demons happen more often, a victim goes to bed wearing a consecrated old alb (these clothes are kept in the church for "such attacks"). When this does not help too, then epitrakhiy is added, and the wreath is put on the head. Also, seven consecrated things have to lie around the bed: holly dora (bread), watch night dora, holly water, a consecrated knife, a consecrated wreath, "ozhog" and chalk. A circle is drawn with that consecrated chalk around the bed." [8, p. 31-32]. F. Potushnyak partly explained a symbolical meaning of those things which were used in that ritual: "All these things are holly even after the following usage of them in real life; a wreath symbolizes purity and innocence of the object" [8, p. 32]. These things became very strong talismans which protected people against a dead person. A dead "walks around the bed, gets angry, appears, scares and howls" [8, p. 32]. At the same time, according to the folk beliefs of Transcarpathia, if a person stays alone and goes out of the circle drawn around the bed with consecrated chalk, the dead will kill this person immediately, because "spirits have power only over one person." [8, p. 32]. Sometimes to get rid of a demonic dead person this ritual has to be performed ninth times.

In his article F. Potushnyak identified two types of intimacy between a person and a representative from the beyond world: 1) willing, if they loved each other (a dead husband or wife comes as a night guest), 2) unwilling (a devil, a demon or a two-soul man make personal contact if a person has been a hostage of sin or destructive amoral behavior in some sphere). "A devil can have sexual intercourse with a woman without her consent if there is a reason for that (as with witches during Sabbath)" [8, p. 32]. Such folk belief about intimacy between a witch and a devil literalizes the psychological process of a woman's 
obsession with archetype Animus, its destructive aspect that is destructive content of collective unconscious. In myths and fairy tales, this process is shown metaphorically: a girl or a princess is captured by a dragon, a demon, or a terrible groom.

According to the folk beliefs of Transcarpathia, a demonic lover of a woman also can be a vampire (a two-soul man turn into a vampire after death). "In dreams she sees him alive, feels his touches. He usually does not leave her until he tortures her at all. - As a result she pines and then dies or gets crazy" [8, p. 32], - wrote F. Potushnyak. According to S. Birkhauser-Oeri, "A human being's meager strength is no match against the devil. In such circumstances one must adopt a religious attitude in the purest sense, as Job did when confronted by the dark side of God, knowing that he too had an advocate in heaven; ... However, a person requires a strong conscious mind and a deeply serious attitude to take the strain of this problem" [1, c. 123]. Appeal to religious rituals and faith in a kind God represents metaphorically human desire to achieve the level of Self and has to become a guaranty of release from the destructive content of the unconscious.

F. Potushnyak remembered folk beliefs according to which contacts between a woman and her dead husband or a demon in the image of him cannot only happen at night but also at midday because it is the time boundary when the door between the human world and the beyond world can be opened: "there are cases when a dead appears at midday in his image and talks to her" [8, p. 32]. A dead wife also could come to her husband if she was a twosoul woman (two souls exist in her body): "A wife can come to her husband (or to the other object chosen by her) in the same way if she is a two-soul woman" [8, p. 32]. Also, there are folk stories about povitrulyas who kidnap "young men and live with them" [8, p. 32], and sometimes they can turn into a human woman because of love. F. Potushnyak pointed out that it is important to separate the images of dead people who come to the alive and demons, two-soul men. Although, the initiators of these meetings with the representatives of the beyond world are people because of their great sadness, and they allow to subordinate their consciousness to these demonic representatives. "Here the reason is a psychic phenomenon which is caused by the clear psycho-physical state, physiological results of which can reflect in human dreams (and dream is perceived as a reality in folk beliefs), - wrote F. Potushnyak. - [...] with it is associated a certain type of images with great sensuality, their influence is great and their echo is heard after awaking" [8, p. 32].

Conclusions. Thus, Potushnyak, like representatives of K.-G.Jung school, stresses a tendency that usual people can interpret unusual, exciting, and awful (that is archetypical) dreams as the stories which happened in reality. In such a way, a different personification of fears and evil appeared (demons, vampires, living dead people), and with them, people contacted at night - the time of their greatest activity. P. Kulish created a wonderful artistic interpretation of folk beliefs and old stories about contacts between a woman and her dead husband in his story "About, why the Peshevtsov pond was dried up in the town of Voronezh". This work is similar to ballad plots, and it is written according to the rules of romanticism, full of symbols and archetypical images. It was demonstrated that the negative aspect of Animus was projected to the image of Hrytsko, and the plot of the story was metaphorical objectification of the psychological process of a woman's obsession with the destructive content of the unconscious. And that was the reason for her death.

\section{СПИСОК ВИКОРИСТАНИХ ДЖЕРЕЛ}

1. Биркхойзер-Оэри С. Мать: архетипический образ в волшебной сказке [под ред. М.-Л. фон Франц; пер. с англ. В.Мершавки]. М. : Когито-Центр, 2006. 255 с.

2. Вархол Н. Народна демонологія українців Словаччини. Свидник, 2017. 448c.

3. Івашків В. Художня, літературознавча і фольклористична парадигма ранньої творчости Пантелеймона Куліша. Монографія. Львів: Видавничий центр ЛНУ імені Івана Франка, 2009. 448c.

4. Кальме О. Трактат о явлениях Ангелов, Демонов и Духов, а также о Привидениях и Вампирах в Венгрии, Моравии, Богемии и Силезии. С приложеним оригинальных документов первых вампирических 
расследований. [Сост. и послеслов. С. Шаргородского]. Б.м.: Salamandra P.V.V., 2013. 338c.

5. Кулиш П. Малороссийские рассказы: 1) O том, от чего в местечке Воронеже высох Пешевцов став; 2) О том, что случилось с казаком Бурдюгом на Зеленой неделе. Киевлянин. 1840. Кн. 1. С. 205-228.

6. Потушняк Ф. Душа в народнім повір'ю села Осій. Науковий збірник товариства «Просвіта» за 1937-1938p. Річник XIII- XIV. Друкарня оо. Василіян в Ужгороді, 1938. C.33-44.

7. Українські міфи, демонологія, легенди. [Упорядкув. М.К. Дмитренко]. К.: Музична Україна, 1992. 144c. (с. 107-113).

8. Ф. П. [Федір Потушняк] «Мертва любов» въ нар. вЊруваню. Литературна недголя. Річник IV. Ужгород, 1944. С.31-33.

9. Чубинский П. П. Труды этнографическо-статистической экспедиции в ЗападноРусский край .Т. 1.: [Верования и суеверия. Загадки и пословицы. Колдовсто]. Санкт-Петербург, 1872. 224c.

\section{REFERENCES}

1. Birkhauser-Oeri S. The Mother: archetypical image in fairy tale [edited by M.-L. fon Franz; trans. from English V. Mershavka]. M.: Kohito-Centre, 2006. 255 p.

2. Varkhol N. Folk demonology of Ukrainians of Slovak Republic [Narodna demonolohiia ukraintsiv Slovachchyny]. Svydnyk, 2017. 448 p.

3. Ivashkiv V. Artistic, literally and folkloristic paradigm of early works of Panteleimon Kulish [Khudozhnia, literaturoznavcha i folklorystychna paradyhma rannoi tvorchosty Panteleimona Kulisha]. Monograph. Lviv: Piblishing centre of Ivan Franko LNU, 2009. $448 \mathrm{p}$.

4. Calmet O. Tractate about Angels, Demons and Spirits and also about Ghosts and Vampires in Hungary, Moravia, Bohemia and Silesia. With attachment of original documents of first vampire investigation. [cont. and epilogue S. Shargorodskyi]. B.M.: Salamandra P.V.V., 2013. 338 p.

5. Kulish P. Malorussian stories: 1) About, why the Peshevtsov pond was dried up in the town of Voronezh; 2) About what happened to Cossack Butdyug on Green Sunday [Malorossiyskie rasskazyi: 1) O tom, ot chego v mestechke. Voronezhe vyisoh Peshevtsov stav; 2) O tom, chto sluchilos s kazakom Burdyugom na Zelenoy needle]. Kievlyanin. 1840. Book 1. P. 205-228.

6. Potushnyak F. The Soul in folk story of Osiy village [Dusha v narodnim poviriu sela Osii]. Scientific collection of works of "Prosvita" partnership 1937-1938p. Richnyk XIII- XIV. Publishing House of Vasilians in Uzhgorod, 1938. P.33-44.

7. Ukrainian myths, demonology, legends. [Collect M.K. Dmytrenko]. K.: Musical Ukraine, 1992. 144 p. (p. 107-113).

8. F. P. [Fedir Potushnyak]. "Dead Love" in Folk Beliefs [Mertva liubov v nar. viruvaniu]. Lyteraturna nedylia [Literary week]. Richnyk IV. Uzhgorod, 1944. P.3133.

9. Chubynskiy P. P. Works of ethnographical and statistic expedition to the WesternRussian land [Trudyi etnografichesko-statisticheskoy ekspeditsii v Zapadno-Russkiy kray]. V. 1.: [Beliefs and superstitions. Riddles and proverbs. Sorcery]. St. Petersburg, 1872. 224 p.

Received: 03 April, 2020 